\title{
Application of geographic information systems in maternal health: a scoping review
}

\author{
Leila Ahmadian, ${ }^{1}$ Fatemeh Salehi² and Kambiz Bahaadinbeigy ${ }^{3}$
}

${ }^{1}$ Medical Informatics Research Centre, Institute for Futures Studies in Health, Kerman University of Medical Sciences, Kerman, Islamic Republic of Iran. ${ }^{2}$ Health Human Resources Research Centre, School of Management and Information Sciences, Shiraz University of Medical Sciences, Shiraz, Islamic Republic of Iran. ${ }^{3}$ Gastroenterology and Hepatology Research Centre, Institute of Basic and Clinical Physiology Sciences, Kerman University of Medical Sciences, Kerman, Islamic Republic of Iran. (Correspondence to: Fatemeh Salehi: fsalehi891@gmail.com).

\begin{abstract}
Background: Improving maternal health is a global health priority and requires accurate evaluation of factors affecting maternal health. Geographic information systems have been used to explore maternal health problems.

Aims: The aim of this study was to identify studies that used geographic information systems in the field of maternal health care and to determine maternal health and mortality variables visualized on these systems.

Methods: This was a scoping review in which we systematically searched PubMed and Science Direct for studies that used geographic information systems to evaluate maternal health care. We included all relevant cross-sectional studies published in English between December 1995 and December 2017. We extracted the following information from each study included: study year, region, objectives, type of geographic information system used, variables visualized by the geographic information system, and all other variables examined that related to maternal health.

Results: Of 5240 articles initially retrieved, 40 were included for detailed review. Most of the studies $(n=32)$ were done in developing countries in Africa, Asia, and Latin America and the Caribbean. Most of the studies $(n=33)$ visualized mothers' distance to health facilities and travel time to health care centres on geographic information systems. Other factors examined included antenatal care capacity $(n=4)$ and capacity of maternal health services $(n=3)$.

Conclusions: Comprehensive research on the application of geographic information systems in maternal care is lacking. Most studies applied simple descriptive mapping of spatial distribution patterns with a few relevant variables.

Keywords: geographic information system; maternal health; maternal health services; health services research

Citation: Ahmadian L; Salehi F; Bahaadinbeigy K. Application of geographic information systems in maternal health: a scoping review. East Mediterr Health J. 2020;26(11):1403-1414. https://doi.org/10.26719/emhj.20.095

Received: 28/06/18; accepted: 26/09/19

Copyright (c) World Health Organization (WHO) 2020. Open Access. Some rights reserved. This work is available under the CC BY-NC-SA 3.0 IGO license (https://creativecommons.org/licenses/by-nc-sa/3.o/igo).
\end{abstract}

\section{Introduction}

Maternal health is a globally important health challenge. Maternal health refers to the health of women during pregnancy, childbirth and the postpartum period (1). According to the World Health Organization (WHO) the global maternal mortality rate is unacceptably high and about 810 maternal deaths occur daily around the world with $94 \%$ of all maternal deaths occurring in developing countries (2). In 2015, 295000 women died following pregnancy related complications - most of these deaths were in low-resource settings and most could have been prevented (2).The Sustainable Development Goals (SDGs) now call for an acceleration in progress in order to achieve a global maternal mortality rate of 70 maternal deaths per 100000 live births, or less, by 2030 (3). Achieving this global goal will require countries to reduce their maternal mortality rate by at least $7.5 \%$ each year between 2016 and 2030 (3). Reducing maternal mortality was introduced globally as an important health priority in the United Nations Millennium Development Goals (4). Precise evaluation of the maternal mortality rate is the first step to reducing this rate.

Extensive implementation of various software and information technology services in recent years has helped health experts to improve health care. These improvements have helped health care professionals work more efficiently and effectively $(5,6)$. Recently, researchers have started to apply geographic information systems (GIS) to explore maternal and newborn health problems (7-9). GIS help to show regional variations and abnormal patterns of health characteristics. Through the use of GIS, researchers can gain insight into the use of health services and expose health problems and environmental risks. This technology can be easily used by non-geographers with basic computer literacy and map-reading skills (10). The use of GIS is a means to effectively link and analyse the range of data necessary to address complex questions in health promotion, public health, community medicine, epidemiology, and other fields (11).

Despite a number of reviews on the use of GIS in maternal health (12-16), to the best of our knowledge, no review has collectively analysed the results of studies to determine maternal health and mortality factors visualized through GIS. Some studies have shown that the application of GIS in maternal health can help decision-making on policies to reduce maternal problems and improve maternal care outcomes $(17,18)$. Therefore, 
we did a scoping review to identify GIS studies related to maternal health care to determine maternal health and mortality factors (variables) visualized through GIS. We also summarized other variables investigated, but not visualized through GIS, to get a general overview of all evaluated variables in the included studies. The results of our review can be used to help in planning to reduce preventable causes of maternal health problems. Our results can also help determine gaps in the use of these types of data and provide a road map to guide more precise studies on various aspects of maternal health.

\section{Methods}

\section{Search terms}

We searched for relevant articles in English from 1995 to 2017 using PubMed and Science Direct databases. We used two groups of key search terms. Group A included GIS-related terms: GIS; geographic information system; risk mapping; spatial analysis; spatial data; GPS; and health mapping. Group B included terms related to maternal health: maternal mortality; maternal health; maternal care; pregnancy; delivery; and maternal death. Our search strategy was as follows: first we used "OR" to combine the terms within each group A and B separately. Then, we combined keywords from the two groups using the "AND" operator to find all the studies that used GIS in the field of maternal care. We then limited the search in both databases to humans and studies published in English.

\section{Inclusion and exclusion criteria}

The inclusion criteria were: cross-sectional study related to the use of GIS in maternal health care; published between December 1995 and December 2017; in English; and on a human population. The exclusion criteria were: review studies, editorials, commentaries and letters; studies that had not visualized data on GIS; and articles not in English.

\section{Review strategy}

Two reviewers independently screened and assessed the titles and abstracts of the retrieved articles. The reviewers met and reached consensus at the end of the screening process. In cases of disagreement, a third independent reviewer was consulted to resolve the disagreement. We compared the results of the independent screenings using the kappa statistic (kappa $=8.6$ ). The reviewers were blinded to each other's decisions to control for assessment bias. We also checked the reference lists of the articles retrieved for other relevant studies. We developed a data collection form and extracted the following information from each paper: study year, region, objectives, GIS application type, variables visualized by GIS, and all other variables examined that related to maternal health. We examined the extraction forms for coverage, clarity and content validity in several meetings. We divided the extracted variables from the studies into two groups: subvariables and variables directly visualized on GIS. Based on expert consensuses and in order to better report on the variables, we classified the subvariables into six categories: (1) maternal factors, (2) socioeconomic factors, (3) health care service factors, (4) ecological determinant factors, (5) environmental factors, and (6) health related factors.

\section{Results}

\section{Study selection}

In our initial search of the online databases we found 5240 articles (Figure 1). After our first screening of titles and abstracts based on out inclusion and exclusion crite-

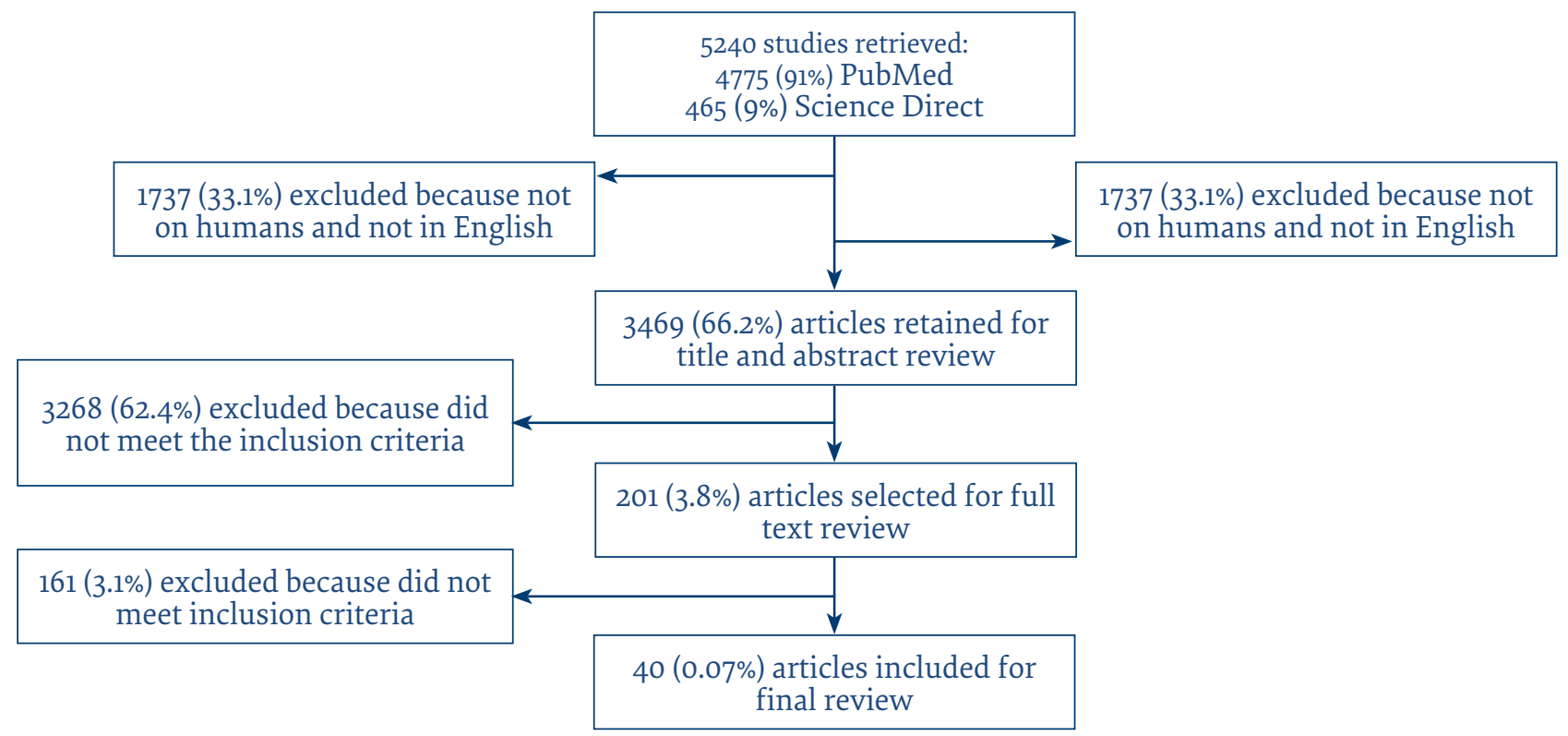


ria, we retained 201 eligible articles for further full-text review. Based on this review of full texts, we excluded 161 articles as they did not meet the inclusion criteria, and retained 40 articles for detailed analysis.

\section{Included studies}

Of the 40 articles we retained, all were journal papers. Table 1 gives a description of the 40 studies - publication year, objectives, region and data sources. The oldest articles were published in 2004 (57,58). The number of studies investigating the application of GIS for maternal care has increased since 2010. Most of the studies $(n=29)$ were conducted in developing countries in Afri$\mathrm{ca}$, Asia, and Latin America and the Caribbean (19-23,26$31,33,34,36,37,39-43,45-50,53,55,58)$ and 11 were conducted in developed countries in Europe, North America, Australia, New Zealand, and Japan $(24,25,32,35,38,44,51,52,5$ $4,56,57)$. Nearly half of the studies $(n=16)$ were done in Africa because of its high maternal and infant mortality rates $(21,23,26,28,31,36,39-42,46-50,58)$, nine were done in Asia $(19,20,22,27,34,37,43,53,55), 11$ in the Americas and the Caribbean $(24,25,29,30,32,33,44,45,51,52,54)$, three in Europe $(35,57,56)$ and one in Oceania $(38)$.

Each study presented data on one country/region, except one study which provided data on four countries (27). Multiple data resources were used to conduct the studies. The source of data in 15 of the studies was national statistics and censuses (Table 1). Other sources of data included, among others, results of other previous surveys $(n=11)$, interviews with women and health staff $(n=5)$ health registries $(n=6)$.

Geographic access to health services was the most common factor examined $(n=22)$ in the included studies $(20,22,25,26,28,30,35,37,39,40,41,43,44-47,49,51,52,56-58)$. Other common factors examined included antenatal care capacity $(19,25,42,55)$ and capacity of maternal health services $(21,48,53)$.

Most studies $(n=28)$ used the spatial analysis of the GIS software such as network analysis, buffer, hot spots and Moran techniques (19,22,23,26-29,31-35,37-45,48$50,52,53,55,56)$. Other studies $(n=10)$ used spatial mapping $(20,21,24,25,30,36,51,54,57,58)$ and two used spatial modelling techniques $(46,47)$.

Many of the studies that used GIS in maternal health focused on potential geographic access to care on the basis of the spatial distribution of health facilities $(27,35-37,44,46,47,51,52,56)$. Some investigated the effect of geographic access on mortality and care utilization $(24,33,49,55)$. Other studies modelled the availability of and access to emergency obstetric care $(22,28,43,50)$.

The geospatial unit of analysis in 16 studies was the national level $(27,28,29,31,35,36,39,40,44,46,48$ $50,52,56,58)$. Most of the studies $(n=24)$ used ArcGIS (Esri, Redlands, California, United States of America) $(19-21,24,25,27,31,32,34,36-39,42-47,50,51,53-55)$ to analyse the data, 10 studies used other types of GIS software - ArcView, QGIS, ArcInfo - (22,26,28-30,35,41,49,56,58), and six did not state which software was used to analyse the data $(27,33,40,47,52,57)$.

Variables extracted from the studies are shown in Table 2. Many studies visualized the variables: distance to health facilities $(n=16)$ and travel time to health care centres $(n=17)$. Other frequently mapped variables were spatial distribution of health services and emergency obstetric care $(n=11)$. Socioeconomic and sociocultural variables, such as women's educational level $(n=10)$ and household wealth $(n=9)$, were often investigated.

\section{Discussion}

The findings of our study show that special attention has been paid to geographic access and travel time to health services in published literature on maternal health. Other important reported variables included: maternal age, maternal educational level, household wealth, residential area, distribution of health services, and availability of emergency obstetric care facilities per population.

Determining the distribution of human resources (obstetricians/gynaecologists, maternity nurses and midwives) can show imbalances in the distribution of health personnel. The findings of some research has shown that the educational level of women was strongly correlated with the maternal mortality rate (59-63). The results of our study also showed that mothers' educational level was frequently reported in the included studies. Educational level has a positive influence on autonomy, awareness of health services, the health-seeking behaviour, responsibility and knowledge of self-care and healthy lifestyles (64) and can directly and indirectly contribute to a reduction in maternal mortality. Some believe that education may have a more important role compared to economic indicators, such as income, clean water supply and sanitary sewer access (65). Maternal age was examined as the underlying variable in many of the studies we reviewed, and is a key variable because older women are at a higher risk of death and complications during pregnancy or delivery $(66,67)$. The risk of pregnancy-related death for mothers over 40 years between 1998 and 2005 has been reported to be six times higher compared with teenagers $(68,69)$. Others research has found that young adolescents $(<15$ years old) face a higher risk of complications and death as a result of pregnancy $(70,71)$. The residential area of pregnant woman is also an important factor. Higher maternal mortality rates have been reported in women living in rural areas and poorer communities (2). The fact that most of the studies included in our review were conducted in developing countries, especially in Africa, is understandable as, according to WHO, $94 \%$ of all maternal deaths occur in developing countries (2) and factors that threaten the health of mothers are more common in these countries.

Some research has provided evidence that comorbid conditions such as high blood pressure, diabetes and cardiac diseases contribute to maternal deaths (72). Others showed that direct pregnancy complications are 
Table 1 Description of the included studies

\begin{tabular}{|c|c|c|c|c|}
\hline Author & $\begin{array}{l}\text { Publication } \\
\text { year }\end{array}$ & Objectives of the study & Country $^{a}$ & Data sources \\
\hline Ansariade and Manderson, (19) & 2015 & $\begin{array}{l}\text { Determine the influence of urban and } \\
\text { rural settings on antenatal care and } \\
\text { birthing decisions and investigate if } \\
\text { women's decision on antenatal care } \\
\text { and birth assistance are geographically } \\
\text { clustered }\end{array}$ & $\begin{array}{l}\text { Indonesia, } \\
\text { Sulawesi }\end{array}$ & $\begin{array}{l}\text { Structured interview with women } \\
\text { who delivered }\end{array}$ \\
\hline Jain, et al. (20) & 2015 & $\begin{array}{l}\text { Assess the influence of economic and } \\
\text { geo- graphic access to health facilities } \\
\text { on institutional deliveries }\end{array}$ & Pakistan & $\begin{array}{l}\text { Health facilities; and household } \\
\text { surveys }\end{array}$ \\
\hline Tabatabai, et al. (21) & 2014 & $\begin{array}{l}\text { Map and analyse the capacities of } \\
\text { public and private hospitals to provide } \\
\text { maternal health care }\end{array}$ & $\begin{array}{l}\text { United Republic } \\
\text { of Tanzania, } \\
\text { Ruvuma }\end{array}$ & $\begin{array}{l}\text { Hospital questionnaire; population } \\
\text { census dataset }\end{array}$ \\
\hline Sabde, et al. (22) & 2014 & $\begin{array}{l}\text { Identify potential areas for further } \\
\text { interventions to increase the } \\
\text { effectiveness of the emergency obstetric } \\
\text { transport system }\end{array}$ & $\begin{array}{l}\text { India, Madhya } \\
\text { Pradesh }\end{array}$ & Interviews with parturient women \\
\hline Mwaliko, et al. (23) & 2014 & $\begin{array}{l}\text { Determine the association between } \\
\text { the place of delivery and the distance } \\
\text { of a household from the nearest health } \\
\text { facility, and assess the demographic } \\
\text { characteristics of households with } \\
\text { a delivery within a demographic } \\
\text { surveillance system }\end{array}$ & Kenya, western & $\begin{array}{l}\text { Database of Webuye health and } \\
\text { demographic surveillance system; } \\
\text { structured interviews with trained } \\
\text { field assistants }\end{array}$ \\
\hline Detres, et al. (24) & 2014 & $\begin{array}{l}\text { Examine how GIS maps can be used } \\
\text { by local organizations to engage } \\
\text { the community in the discussion of } \\
\text { maternal and child health data to } \\
\text { modify service delivery }\end{array}$ & USA, Florida & $\begin{array}{l}\text { Florida vital statistics birth and } \\
\text { infant death records }\end{array}$ \\
\hline Brown, et al. (25) & 2014 & $\begin{array}{l}\text { Determine maternal ground transport } \\
\text { times from community hospitals to the } \\
\text { nearest hospital offering comprehensive } \\
\text { (level III) neonatal care }\end{array}$ & USA & $\begin{array}{l}\text { US census tract data; American } \\
\text { hospital association annual survey }\end{array}$ \\
\hline Nesbitt, et al. (26) & 2014 & $\begin{array}{l}\text { Compare methods to measure potential } \\
\text { spatial access to delivery care in low- } \\
\text { and middle-income countries }\end{array}$ & Ghana & $\begin{array}{l}\text { Kintampo Health Research Centre } \\
\text { surveillance data; health facility } \\
\text { assessment; Ghana registered } \\
\text { midwives association }\end{array}$ \\
\hline Tatem, et al. (27) & 2014 & $\begin{array}{l}\text { Present methods to estimate women of } \\
\text { childbearing age, and pregnancies and } \\
\text { live births in relation to current health } \\
\text { infrastructure }\end{array}$ & $\begin{array}{l}\text { Afghanistan } \\
\text { Bangladesh, } \\
\text { Ethiopia, United } \\
\text { Republic of } \\
\text { Tanzania }\end{array}$ & $\begin{array}{l}\text { Household survey data; United } \\
\text { Nations statistics; new estimates } \\
\text { of stillbirths, miscarriages and } \\
\text { abortions from the Guttmacher } \\
\text { Institute }\end{array}$ \\
\hline McKinnon, et al. (28) & 2014 & $\begin{array}{l}\text { Assess the effect of distance to } \\
\text { emergency obstetric and newborn care } \\
\text { services on early neonatal mortality } \\
\text { and examine whether proximity to } \\
\text { services contributes to socioeconomic } \\
\text { inequalities in early neonatal mortality }\end{array}$ & Ethiopia & $\begin{array}{l}\text { Ethiopian Demographic and } \\
\text { Health Survey; Ethiopian national } \\
\text { emergency obstetric and newborn } \\
\text { care needs assessment (Ethiopian } \\
\text { Ministry of Health); questionnaire } \\
\text { filled by women }\end{array}$ \\
\hline Wang, et al. (29) & 2014 & $\begin{array}{l}\text { Estimate the influence of service } \\
\text { readiness at health facilities on women's } \\
\text { use of facility delivery care for delivery }\end{array}$ & Haiti & $\begin{array}{l}\text { Haiti Demographic and Health } \\
\text { Survey; Haiti service provision } \\
\text { assessment survey }\end{array}$ \\
\hline Gaspar, et al. (30) & 2014 & $\begin{array}{l}\text { Evaluate the spatial distribution of } \\
\text { public sector obstetric care }\end{array}$ & $\begin{array}{l}\text { Brazil, Belo } \\
\text { Horizonte }\end{array}$ & $\begin{array}{l}\text { A system of obstetric information } \\
\text { Municipal (SISMater }{ }^{\circledR} \text {, } \\
\text { Department of Health of Belo } \\
\text { Horizonte (SMSA-BH); , cohort of } \\
2956 \text { newborns }\end{array}$ \\
\hline Benedict, et al. (31) & 2014 & $\begin{array}{l}\text { Explore geographical patterns in the } \\
\text { risk of not utilizing using a skilled birth } \\
\text { attendant during childbirth in women } \\
\text { of different socioeconomic backgrounds }\end{array}$ & Ghana & $\begin{array}{l}\text { Ghana Demographic and Health } \\
\text { Survey; interviews with women }\end{array}$ \\
\hline Blake, et al. (32) & 2014 & $\begin{array}{l}\text { Explore the geographic relationships } \\
\text { among between dairy farms, nitrate } \\
\text { levels in drinking water, low birth } \\
\text { weight and socioeconomic data at the } \\
\text { Zip code level }\end{array}$ & USA, California & Zip codes, US census \\
\hline
\end{tabular}




\begin{tabular}{|c|c|c|c|c|}
\hline Author & $\begin{array}{c}\text { Publication } \\
\text { year }\end{array}$ & Objectives of the study & Country ${ }^{\mathrm{a}}$ & Data sources \\
\hline Almeida, et al. (33) & 2014 & $\begin{array}{l}\text { Identify spatial patterns of in } \\
\text { distribution of overall, early, and late } \\
\text { neonatal mortality rates }\end{array}$ & Brazil, São Paulo & $\begin{array}{l}\text { Department of information } \\
\text { systems and information } \\
\text { technology of the Brazilian } \\
\text { national healthcare system }\end{array}$ \\
\hline Arslan, et al. (34) & 2013 & $\begin{array}{l}\text { Determine the spatial patterns of } \\
\text { perinatal mortality, examine whether } \\
\text { regional differences exist and whether } \\
\text { these differences are linked to regional } \\
\text { risk factors }\end{array}$ & Turkey, Kocaeli & Registry of births and deaths \\
\hline Engjom, et al. (35) & 2013 & $\begin{array}{l}\text { Assess the availability of obstetric } \\
\text { institutions, the risk of unplanned } \\
\text { delivery outside an institution and } \\
\text { maternal morbidity in a national setting } \\
\text { in which the number of institutions } \\
\text { declined from } 95 \text { to } 51 \text { during over } 30 \\
\text { years }\end{array}$ & Norway & $\begin{array}{l}\text { Census data; Statistics Norway; } \\
\text { medical birth registry }\end{array}$ \\
\hline Sudhof, et al. (36) & 2013 & $\begin{array}{l}\text { Identify potential gaps in access to } \\
\text { emergency obstetric care }\end{array}$ & $\begin{array}{l}\text { Rwanda, } \\
\text { Kayonza }\end{array}$ & $\begin{array}{l}\text { Birth registries at in eight health } \\
\text { centres and the district hospital }\end{array}$ \\
\hline Song, et al. (37) & 2013 & $\begin{array}{l}\text { Assess spatial accessibility to maternity } \\
\text { units }\end{array}$ & China, Shenzhen & $\begin{array}{l}\text { Website of Shenzhen Health and } \\
\text { Population and Family Planning } \\
\text { Commission }\end{array}$ \\
\hline Chong, et al. (38) & 2013 & $\begin{array}{l}\text { Assess the usefulness of geospatial } \\
\text { methods in identifying communities at } \\
\text { high risk of smoking during pregnancy } \\
\text { and timing of the first antenatal visit }\end{array}$ & $\begin{array}{l}\text { Australia, New } \\
\text { South Wales }\end{array}$ & New South Wales health ministry \\
\hline Bowie C, et al. (39) & 2013 & $\begin{array}{l}\text { Evaluate geographical access to health } \\
\text { care facilities }\end{array}$ & Malawi & $\begin{array}{l}\text { Malawi census; Ministry of Health } \\
\text { facility surveys }\end{array}$ \\
\hline Masters, et al. (40) & 2013 & $\begin{array}{l}\text { Estimate travel times between } \\
\text { populations and health facilities using } \\
\text { geospatial techniques }\end{array}$ & Ghana & Ghanaian Ministry of Health \\
\hline Yao, et al. (41) & 2013 & $\begin{array}{l}\text { Present a geographical perspective on } \\
\text { access to sexual and reproductive health } \\
\text { care for rural women }\end{array}$ & $\begin{array}{l}\text { Mozambique, } \\
\text { Gaza province }\end{array}$ & Population survey data \\
\hline O'Meara, et al. (42) & 2013 & $\begin{array}{l}\text { Assess spatial autocorrelation in uptake } \\
\text { of antenatal care and relationship to } \\
\text { individual, household and village-level } \\
\text { factors }\end{array}$ & Kenya, western & Survey data \\
\hline Monyet al. (43) & 2013 & $\begin{array}{l}\text { Investigate the availability and } \\
\text { distribution of emergency obstetric care } \\
\text { services in eight northern districts of } \\
\text { Karnataka State in south India }\end{array}$ & India, Karnataka & $\begin{array}{l}\text { Combination of self-reporting, } \\
\text { record review and direct } \\
\text { observation }\end{array}$ \\
\hline Brown, et al.(44) & 2012 & $\begin{array}{l}\text { Determine the percentage of women of } \\
\text { reproductive age living within a } 30-\text { and } \\
60 \text { - minute drive time of the nearest } \\
\text { tertiary care perinatal centre }\end{array}$ & USA & US census tract data \\
\hline Friedman, et al. (45) & 2012 & $\begin{array}{l}\text { Evaluate the effect of an inverse } \\
\text { relationship between health care } \\
\text { use and distance to care related to } \\
\text { emergency and essential surgical care }\end{array}$ & $\begin{array}{l}\text { Haiti, central } \\
\quad \text { district }\end{array}$ & $\begin{array}{l}\text { Retrospective review of operative } \\
\text { logbooks; Haiti earthquake data } \\
\text { portal }\end{array}$ \\
\hline Gething, et al. (46) & 2012 & $\begin{array}{l}\text { Develop a uniquely detailed set of } \\
\text { spatially-linked data and a calibrated } \\
\text { geospatial model to undertake a } \\
\text { national audit of geographical access to } \\
\text { maternity care at birth }\end{array}$ & Ghana & $\begin{array}{l}\text { Ghana Ministry of Health; } \\
\text { University of Ghana; project by } \\
\text { the Ghana Ministry of Health } \\
\text { and Ghana Health Service Core; } \\
\text { Welfare Indicator Questionnaire } \\
\text { survey }\end{array}$ \\
\hline Blanford, et al. (47) & 2012 & $\begin{array}{l}\text { Analyse the physical access of } \\
\text { populations to health facilities with } \\
\text { an emphasis on the effect of seasonal } \\
\text { conditions and the implications of these } \\
\text { conditions for availability of adequate } \\
\text { health services, and provision of drugs } \\
\text { and vaccinations }\end{array}$ & Niger & $\begin{array}{l}\text { FAO Geo Network Portal; Niger } \\
\text { Ministry of Health }\end{array}$ \\
\hline
\end{tabular}




\begin{tabular}{|c|c|c|c|c|}
\hline Author & $\begin{array}{l}\text { Publication } \\
\text { year }\end{array}$ & Objectives of the study & Country $^{a}$ & Data sources \\
\hline Massey, et al. (48) & 2011 & $\begin{array}{l}\text { Identify priority regions for the } \\
\text { expansion of human resources for } \\
\text { health }\end{array}$ & Senegal & $\begin{array}{l}\text { National agency for demography } \\
\text { and statistics; WHO }\end{array}$ \\
\hline Gabrysch, et al. (49) & 2011 & $\begin{array}{l}\text { Quantify the effects of distance to care } \\
\text { and level of care on women's use of } \\
\text { health facilities for delivery }\end{array}$ & Zambia & $\begin{array}{l}\text { National household data from the } \\
\text { Zambian Demographic and Health } \\
\text { Survey; national facility data from } \\
\text { the Zambian health facility census }\end{array}$ \\
\hline Bailey, et al. (50) & 2011 & $\begin{array}{l}\text { Provide a set of multicriteria decision } \\
\text { analyses to help health planners make } \\
\text { informed decisions about interventions } \\
\text { to increase access to emergency services }\end{array}$ & Ethiopia & $\begin{array}{l}\text { Ethiopian national survey on } \\
\text { baseline assessment of emergency } \\
\text { obstetric and newborn care; spatial } \\
\text { population data from Land } \mathrm{Scan}^{\mathrm{TM}} \\
\text { population data }\end{array}$ \\
\hline Gjesfjeld \& Jung. (51) & 2011 & $\begin{array}{l}\text { Examine maternity care access for } \\
\text { expectant mothers }\end{array}$ & USA, Dakota & $\begin{array}{l}\text { North Dakota department of vital } \\
\text { records }\end{array}$ \\
\hline Grzybowski, et al. (52) & 2011 & $\begin{array}{l}\text { Systematically document newborn and } \\
\text { maternal outcomes in terms of travel } \\
\text { distance to access the nearest maternity } \\
\text { services with caesarean section } \\
\text { capability }\end{array}$ & $\begin{array}{l}\text { Canada, British } \\
\text { Columbia }\end{array}$ & $\begin{array}{l}\text { British Columbia Perinatal Health } \\
\text { Program }\end{array}$ \\
\hline Fisher and Myers (53) & 2011 & $\begin{array}{l}\text { Test the appropriateness of new, } \\
\text { inexpensive and simple GIS tools in } \\
\text { poorly resourced areas of a developing } \\
\text { country }\end{array}$ & $\begin{array}{l}\text { Indonesia, Nusa } \\
\text { Tenggara Timur }\end{array}$ & $\begin{array}{l}\text { Cybertracker; health data collected } \\
\text { by district and subdistrict health } \\
\text { officer departments and clinics }\end{array}$ \\
\hline Bloch, et al. (54) & 2011 & $\begin{array}{l}\text { Examine spatial patterns of } \\
\text { neighbourhood contextual factors of } \\
\text { stress with preterm birth and country of } \\
\text { birth (USA or elsewhere) }\end{array}$ & $\begin{array}{l}\text { USA, } \\
\text { Philadelphia }\end{array}$ & $\begin{array}{l}\text { Census data; de-identified } \\
\text { geocoded Philadelphia birth } \\
\text { records; publicly available } \\
\text { Philadelphia police department } \\
\text { crime statistics. }\end{array}$ \\
\hline Målqvist, et al. (55) & 2010 & $\begin{array}{l}\text { Examine the association between } \\
\text { distance from the mother's home to } \\
\text { the closest health facility and neonatal } \\
\text { mortality, and investigating investigate } \\
\text { the influence of distance on patterns of } \\
\text { perinatal health care use }\end{array}$ & $\begin{array}{l}\text { Viet Nam, } \\
\text { Quang Ninh }\end{array}$ & $\begin{array}{l}\text { Interviews with mothers and staff; } \\
\text { medical records; VidaGIS database }\end{array}$ \\
\hline Pilkington, et al. (56) & 2008 & $\begin{array}{l}\text { Describe the effect of maternity unit } \\
\text { closures on distance and mean travel } \\
\text { time between pregnant women's homes } \\
\text { and maternity units }\end{array}$ & France & $\begin{array}{l}\text { French national perinatal surveys; } \\
\text { vital statistics registries }\end{array}$ \\
\hline Dummer, et al. (57) & 2004 & $\begin{array}{l}\text { Investigate whether geographical } \\
\text { accessibility to hospitals affected the } \\
\text { risk of infant mortality }\end{array}$ & $\begin{array}{l}\text { England, } \\
\text { Cumbria }\end{array}$ & Cumbrian births database \\
\hline Heard, et al. (58) & 2004 & $\begin{array}{l}\text { Identify whether access to reproductive } \\
\text { health services partly explains the use of } \\
\text { modern contraception }\end{array}$ & Malawi & $\begin{array}{l}\text { Malawi health facilities inventory; } \\
\text { Malawi demographic and health } \\
\text { survey }\end{array}$ \\
\hline
\end{tabular}

WHO=World Health Organization; GIS=geographical information system; USA=United States of America; FAO=Food and Agriculture Organization.

${ }^{a}$ Where the region is not specified, the study done at the national level.

the leading causes of maternal deaths (73). Little attention was paid to these health factors in the studies in our review, which may be because the data sources used in these studies did not include these kind of health-related factors.

The articles included in our study used and combined various data sources, which provides better results and allows greater understanding. Our review showed that the effects variables such as environmental factors, political policies, exposure to infectious diseases during pregnancy and nutritional status on maternal mortality are largely ignored. Evidence indicates important linkages between the water and sanitation environment and maternal and perinatal mortality $(34,74)$. Although we believe there is a relation between the above-mentioned groups of variables and maternal mortality, it is difficult to know which variable is the strongest determinant. In addition, the strength of the association of these variables with maternal mortality may differ by region. However, proposing a dataset for research in this field would direct researchers to a unique guideline and standard data set (75). Despite the rapid growth of technologies and health information systems, most of health information systems do not merge patients' records with external datasets. This fact can explain why isolated data systems cannot be used to recognize how the physical and environmental context of each patient influences his/her health choices 


\section{Table 2 Frequency of variables examined in the studies}

Background variables

No. $(\%)(n=40)$

\section{Maternal factors}

Maternal age

$11(27.5)$

Antepartum haemorrhage

$1(25.0)$

Antenatal care visits

5 (12.5)

Use of contraception (family planning)

2 (5.0)

Number of children

1 (25.0)

Parity

5 (12.5)

Newborn outcomes

1 (25.0)

Complications during last pregnancy

1 (25.0)

Gestational age

Birth weight

4 (10.0)

Multiple births

Type of delivery (normal or caesarean section, emergency or elective)

Birth order and interval

\section{Socioeconomic factors}

Educational level of pregnant woman

Parents' educational level

Household wealth

9 (22.5)

Mother's ethnicity

Mother's occupation

Women's autonomy within society

Marital status

4 (10.0)

Employment of head of household (employed/unemployed)

Sex of head of household

Sex of the newborn

Sex of infants who have died

$1(25.0)$

Religion

Exposure to media

Exposure to family planning messages

Residential area(urban, rural)

Year of birth of mother

\section{Health care service factors}

Human resources

Maternity and delivery beds

Type of facility

Level of delivery care (basic or comprehensive)

Readiness of facilities to provide good delivery care

Type of birth attendant (skilled or traditional)

Place of delivery

\section{Ecological determinant factors}

Level of social vulnerability in catchment area

Proportion of indigenous people in catchment area

Environmental factors

Drinking-water quality

\section{Health-related factors}

Chronic diseases (high blood pressure, diabetes, heart disease)

Smoking and tobacco use during pregnancy 


\begin{tabular}{lc}
\hline Table 2 Frequency of variables examined in the studies (Concluded) & No. (\%) (n= 40) \\
\hline Background variables & $3(7.5)$ \\
\hline Geographic factors visualized on GIS & $16(40.0)$ \\
\hline Season of birth & $17(42.5)$ \\
Distance to facility & $4(10.0)$ \\
Travel time to facility and emergency obstetric care & $11(27.5)$ \\
Type of transport taken to facility (on foot, vehicle, ambulance) & $1(25.0)$ \\
Distribution health services and emergency obstetric care facilities per population & $5(12.5)$ \\
Distribution of human resources & $1(25.0)$ \\
Childbirths per region at health facilities, at home, or outside home or health facility (e.g. in & $4(10.0)$ \\
car/ambulance) & $2(5.0)$ \\
Distribution of childbirths occurring unassisted by health professionals & $2(5.0)$ \\
Distribution of early neonatal, early fetal and late fetal deaths & $2(5.0)$ \\
Distribution of woman receiving antenatal care & $1(25.0)$ \\
Distribution of women who had caesarean sections & $1(25.0)$ \\
Distribution of women of reproductive age & $1(25.0)$ \\
Distribution of private and public maternity units & $1(25.0)$ \\
Distribution of maternity beds & $1(25.0)$ \\
Distribution of women with high-risk pregnancies & \\
Distribution of births with poor neonatal outcomes (national) & \\
Distribution of facility-based peripartum fetal care &
\end{tabular}

and health outcomes. Therefore, the use of tools such as GIS is needed to evaluate these associations. Pregnant women's access to health care centres and improvement in their health status are basic rights of women and can be thought of as an index of development in any country.

Our study had some limitations. First, the variables examined in some of the studies were not clearly reported and may have been missing. Second, we classified the extracted variables based on expert consensus for a better reporting. As such, we may have misclassified some variables. Third, although we reported the effect of these variables on maternal care, we could not undertake a precise analysis because of the large number of descriptive studies and the many different objectives of the studies. We only included articles in English and searched only two databases which is another limitation as there might have been some relevant articles published in other languages and included in other databases.

\section{Conclusion}

Our review highlights the various applications of GIS in examining important variables in maternal care, and the need for programmes to improve the accessibility, use and quality of care for pregnancy and childbirth. Health care planners can use GIS to determine the best location and capacity of new health care facilities, and assess the costs. Furthermore, electronic health technologies, such as telemedicine, may be a way to overcome barriers of geographic access.

\section{Acknowledgement}

We thank Dr Reza Khajouei and Dr Khodadad Sheikhzadeh for their comments.

Funding: None.

Competing interests: None declared. 


\section{Application des systèmes d'information géographique à la santé maternelle : étude exploratoire}

\section{Résumé}

Contexte: L'amélioration de la santé maternelle est une priorité sanitaire à l'échelle mondiale et nécessite une évaluation précise des facteurs qui influent sur la santé des mères. Des systèmes d'information géographique ont été utilisés pour étudier les problèmes de santé maternelle.

Objectifs : La présente étude avait pour objectif d'identifier les travaux de recherche faisant appel aux systèmes d'information géographique dans le domaine des soins de santé maternelle et de déterminer les variables en matière de santé et de mortalité maternelles que ces systèmes permettent de faire apparaître.

Méthodes : Il s'agissait d'une étude exploratoire dans laquelle nous avons systématiquement recherché dans PubMed et Science Direct des études qui utilisaient des systèmes d'information géographique pour évaluer les soins de santé maternelle. Nous avons inclus toutes les études transversales pertinentes publiées en anglais entre décembre 1995 et décembre 2017. Nous avons extrait de chaque étude les informations suivantes : année d'étude, région, objectifs, type de système d'information géographique utilisé, variables mises en évidence par le système d'information géographique, et toutes les autres variables examinées concernant la santé maternelle.

Résultats: Sur 5240 articles initialement récupérés, 40 ont fait l'objet d'une analyse détaillée. La plupart des études $(n=32)$ ont été réalisées dans des pays en développement en Afrique, en Asie, en Amérique latine et dans les Caraïbes. Grâce aux systèmes d'information géographique, la plupart des études $(n=33)$ ont permis de faire ressortir la distance entre le lieu d'habitation des mères et les établissements de santé ainsi que le temps de trajet pour se rendre dans les centres de soins. Les autres facteurs examinés portaient sur les capacités en matière de soins prénatals $(n=4)$ et de santé maternelle $(\mathrm{n}=3)$.

Conclusions: Il n'existe pas de recherche exhaustive sur l'application des systèmes d'information géographique aux soins maternels. La plupart des études ont appliqué une cartographie descriptive simple des schémas de répartition spatiale, complétée par l'ajout de quelques variables pertinentes.

$$
\begin{aligned}
& \text { تطبيق نظم المعلومات الجغر افية في مجال صحة الأم: استعر اض استكشافي }
\end{aligned}
$$

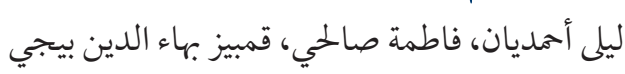

الخلفية: يُعد تحسين صحة الأم أولوية صحية على الصعيد العالمي، ويتطلب تقييلًا دقيقاً للعو امل التي تؤثر على صحة الأم. وقد استُخدمت نُظم

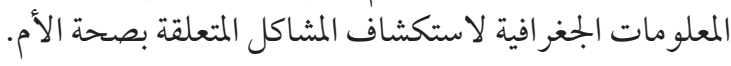

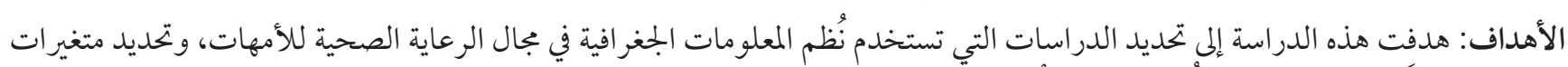

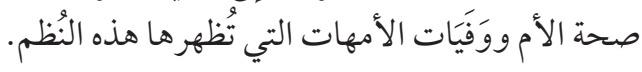

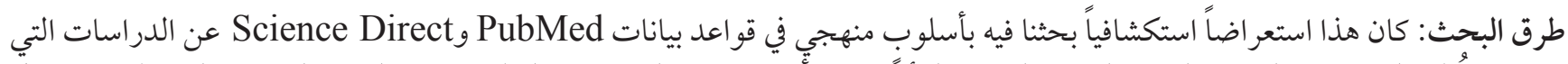

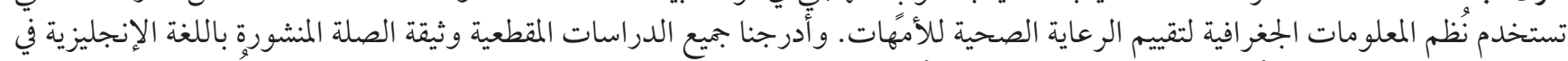

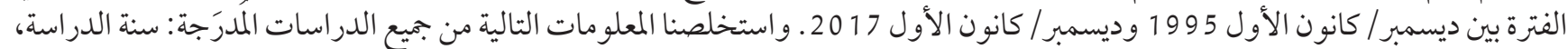

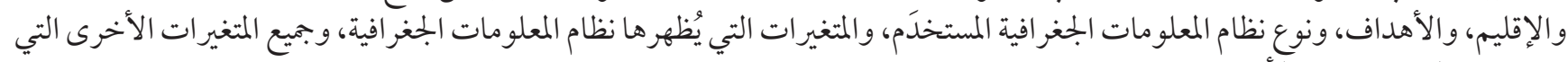
درسناها و المتعلقة بصحة والاهداف الآم.

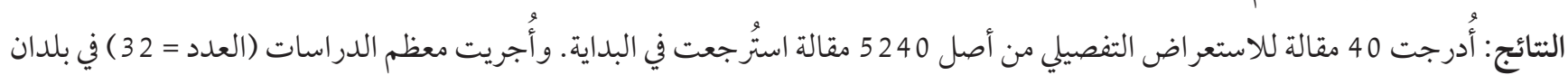

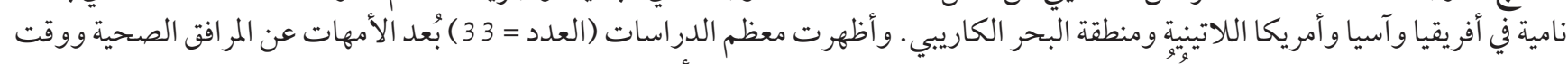

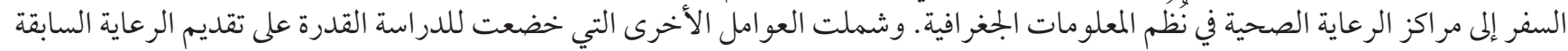

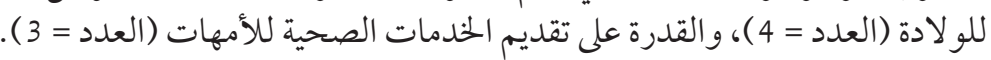

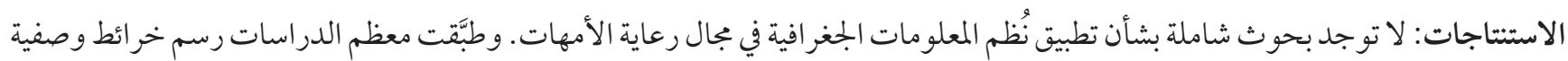
بسيطة لأنماط التوزيع المكاني مع عددٍ قليلٍ من المتغيرات. 


\section{References}

1. Maternal health [website]. Geneva: World Health Organization; 2020 (https://www.who.int/maternal-health/en/, accessed 8 April 2020).

2. Maternal mortality: key facts. Geneva: World Health Organization; 2019 (https://www.who.int/en/news-room/fact-sheets/detail/ maternal-mortality, accessed 8 April 2020).

3. Trends in maternal mortality: 1990 to 2013. Estimates by WHO, UNICEF, UNFPA, The World Bank and the United Nations Population Division. Geneva: World Health Organization; 2014. (https://apps.who.int/iris/bitstream/handle/10665/112682/9789241507226_eng.pdf?sequence=2, accessed 8 April 2020).

4. The Millennium Development Goals Report. New York: United Nations: 2015 (https://www.un.org/millenniumgoals/2015_ MDG_Report/pdf/MDG\%202015\%20rev\%20(July\%201).pdf, accessed 8 April 2020).

5. Ahmadian L, Salehi Nejad S, Khajouei R. Evaluation methods used on health information systems (HISs) in Iran and the effects of HISs on Iranian healthcare: a systematic review. Int J Med Inform. 2015;84(6):444-53. http://doi.org/10.1016/j.ijmedl inf.2015.02.002

6. Ahmadian L, Khajouei R, Salehi Nejad S, Ebrahimzadeh M, Nikkar SE. Prioritizing barriers to successful implementation of hospital information systems. J Med Syst. 2014;38(12):151. http://doi.org/10.1007/s10916-014-0151-9

7. Gabrysch S, Cousens S, Cox J, Campbell OM. The influence of distance and level of care on delivery place in rural Zambia: a study of linked national data in a geographic information system. PLoS Med. 2011;8(1):e1000394. https://doi.org/10.1371/journal

8. Chen SC, Wang JD, Yu JK, Chiang TY, Chan CC, Wang HH, et al. Applying the global positioning system and google earth to evaluate the accessibility of birth services for pregnant women in northern Malawi. J Midwifery Womens Health. 2011;56(1):6874. https://doi.org/10.1111/j.1542-2011.2010.00005.x

9. Simões PP, Almeida RMVR. Geographic accessibility to obstetric care and maternal mortality in a large metropolitan area of Brazil. Int J Gynecol Obstet. 2011;112(1):25-9. https://doi.org/10.1016/j.ijgo.2010.07.031

10. Nykiforuk C, Flaman L. Exploring the utilization of geographic information systems in health promotion and public health (Technical report \#08-001). Edmonton: University of Alberta; 2008 (http://bceohrngis.pbworks.com/f/BP+Exploring +GIS +in +A Public+Health+2008.pdf, accessed 8 April 2020).

11. Nykiforuk CIJ, Flaman LM. Geographic information systems (GIS) for health promotion and public health: a review. Health Promot Pract. 2011:12(1):63-73. https://doi.org/10.1177/1524839909334624

12. Wangia V, Shireman TI. Review of Geographic Variation and Geographic Information Systems (GIS) Applications in Prescription Drug Use Research. Res Social Adm Pharm. 2013;9(6):666-87. https://doi.org/10.1016/j.sapharm.2012.11.006

13. Aimone AM, Perumal N, Cole DC. A systematic review of the application and utility of geographic information systems for exploring disease relationships in paediatric global health research: the case of anaemia and malaria. Int J Health Geogr. 2013;12:1. https://doi.org/10.1186/1476-072X-12-1

14. Makanga PT, Schuurman N, von Dadelszen P, Firoz T. A scoping review of geographic information systems in maternal health. Int J Gynaecol Obstet. 2016:134(1):13-7. https://doi.org/10.1016/j.ijgo.2015.11.022

15. Ebener S, Guerra-Arias M, Campbell J, Tatem AJ, Moran AC, Johnson F, et al. The geography of maternal and newborn health: the state of the art. Int J Health Geogr. 2015;14(1):19. https://doi.org/10.1186/s12942-015-0012-x

16. Palaniyandi M. The role of remote sensing and GIS for spatial prediction of vector-borne diseases transmission: a systematic review. J Vector Borne Dis. 2012;49(4):197-204.

17. Ahmed N. Study reveals inadequate access to EmONC facilities in 24 districts of Bangladesh. Dhaka: icddr,b; 2014 (https://www. icddrb.org/news-and-events/news?id=634\&task=view, accessed 8 April 2020).

18. Amoako-Johnson F, Frempong-Ainguah F, Matthews Z, Harfoot AJP, Nyarko P, Baschieri A, et al. Evaluating the impact of the community-based health planning and services initiative on uptake of skilled birth care in Ghana. PLoS One. 2015;10(3):e0120556. https://doi.org/10.1371/journal.pone.0120556

19. Ansariadi A, Manderson L. Antenatal care and women's birthing decisions in an Indonesian setting: does location matter? Rural Remote Health. 2015;15:2959.

20. Jain AK, Sathar ZA, Haque M. The constraints of distance and poverty on institutional deliveries in Pakistan: evidence from georeference-linked data. Stud Fam Plann. 2015;46(1):21-39. https://doi.org/10.1111/j.1728-4465.2015.00013.X

21. Tabatabai P, Henke S, Sus`ac K, Kisanga OME, Baumgarten I, Kynast-Wolf G, et al. Public and private maternal health service capacity and patient flows in southern Tanzania: using a geographic information system to link hospital and national census data. Glob Health Action. 2014;7:22883. https://doi.org/10.3402/gha.v7.22883

22. Sabde Y, De Costa A, Diwan V. A spatial analysis to study access to emergency obstetric transport services under the public private "Janani Express Yojana" program in two districts of Madhya Pradesh, India. Reprod Health. 2014;11:57. https://doi. org/10.1186/1742-4755-11-57

23. Mwaliko E, Downing R, O'Meara W, Chelagat D, Obala A, Downing T, et al. Not too far to walk: the influence of distance on place of delivery in a western Kenya health demographic surveillance system. BMC Health Serv Res. 2014;14:212. https://doi. org/10.1186/1472-6963-14-212

24. Detres M, Lucio R, Vtucci J. GIS as a Community Engagement Tool: Developing a Plan to Reduce Infant Mortality Risk Factors. Matern Child Health J. 2014; 18:1049-1055. https://doi.org/10.1007/s10995-013-1337-3 
25. Brown SA, Richards ME, Elwell EC, Rayburn WF. Geographical information systems for mapping maternal ground transport to level iii care neonatal centers. Am J Perinatol. 2014;31(4):287-92. https://doi.org/10.1055/s-0033-1348029

26. Nesbitt RC, Gabrysch S, Laub A, Soremekun S, Manu A, Kirkwood BR, et al. Methods to measure potential spatial access to delivery care in low- and middle-income countries: a case study in rural Ghana. Int J Health Geogr. 2014;13:25. https://doi. org/10.1186/1476-072X-13-25

27. Tatem AJ, Campbell J, Guerra Arias M, de Bernis L, Moran A, Matthews Z. Mapping for maternal and newborn health: the distributions of women of childbearing age, pregnancies and births. Int J Health Geogr. 2014;13(1):2. https://doi.org/10.1186/1476072X-13-2

28. McKinnon B, Harper S, Kaufman JS, Abdullah M. Distance to emergency obstetric services and early neonatal mortality in Ethiopia. Trop Med Int Health. 2014;19(7):780-90. https://doi.org/10.1111/tmi.12323

29. Wang W, Winner M, Burgert C, Colston J. Influence of service readiness on use of facility delivery care: a study linking health facility data and population data in Haiti. (DHS working paper, No. 114). Rockville (MD): ICF International; 2014 (https://www. researchgate.net/publication/291343442_Influence_of_Service_Readiness_on_Use_of_Facility_Delivery_Care_A_Study_Linking_Health_Facility_Data_and_Population_Data_in_Haiti, accessed 8 April 20-20).

30. Gaspar JS, Sá T, Reis ZSN, Júnior RFN, Júnior MS, Gusmão RR. Use of geographic information system tools in research on neonatal outcomes in a maternity school in Belo Horizonte - Brazil. Int J Adv Comput Sci Appl. 2014;5(12):91-6.

31. Asamoah BO, Agard A, Cromley EK. Spatial analysis of skilled birth attendant utilization in Ghana. Glob J Health Sci. 2014;6(4). https://doi.org/10.5539/gjhs.v6n4p117

32. Blake SB. Spatial relationships among dairy farms, drinking water quality, and maternal-child health outcomes in the San Joaquin Valley. Public Health Nurs 2014;31(6):492-9. https://doi.org/10.1111/phn.12166

33. Pilkington H, Blondel B, Carayol M, Breart G, Zeitlin J. Impact of maternity unit closures on access to obstetrical care: The French experience between 1998 and 2003. Soc Sci Med. 2008;67:1521-9. https://doi.org/10.1016/j.socscimed.2008.07.021

34. Arslan O, Cepni MS, Etiler N. Spatial analysis of perinatal mortality rates with geographic information systems in Kocaeli, Turkey. Public health. 2013;127:369-79. https://doi.org/10.1016/j.puhe.2012.12.009

35. Engjom HM, Morken NH, Norheim OF, Klungsøyr K. Availability and access in modern obstetric care: a retrospective population-based study. BJOG. 2014;121:290-9. https://doi.org/10.1111/1471-0528.12510

36. Sudhof L, Amoroso C, Barebwanuwe P, Munyaneza F, Karamaga A, Zambotti G, et al. Local use of GIS mapping to improve rural C-section access. Trop Med Int Health. 2013;8:8-26. https://doi.org/10.1111/tmi.12016

37. Song P, Zhu Y, Mao X, Li Q, An L. Assessing spatial accessibility to maternity units in Shenzhen, China. PLoS ONE. 2013;8(7):e70227. https://doi.org/10.1371/journal.pone.0070227

38. Chong SH, Nelson M, Byun R, Harris L, Eastwood J, Jalaludin B. Geospatial analyses to identify clusters of adverse antenatal factors for targeted interventions. Int J Health Geog. 2013;12:46. https://doi.org/10.1186/1476-072X-12-46

39. Bowie C. Recent trends in geographical access to health care facilities in Malawi. Blantyre: Division of Community Health, College of Medicine, University of Malawi; 2013.

40. Masters SH, Burstein R, Amofah G, Abaogye P, Kumar S, Hanlon M. Travel time to maternity care and its effect on utilization in rural Ghana: a multilevel analysis. Soc Sci Med. 2013;93:147-54. https://doi.org/10.1016/j.socscimed.2013.06.012

41. Yao J, Murray AT, Agadjanian V. A geographical perspective on access to sexual and reproductive health care for women in rural Africa. Soc Sci Med. 2013;96:60-8. https://doi.org/10.1016/j.socscimed.2013.07.025

42. Mony PK, Krishnamurthy J, Thomas A, Sankar K, Ramesh BM, Moses S, et al. Availability and distribution of emergency obstetric care services in Karnataka State, south India: access and equity considerations. PLoS ONE. 2013;8(5):e64126. https://doi. org/10.1371/journal.pone.0064126

43. Almeida MCS, Gomes CMS, Nascimento LFC. Spatial analysis of neonatal mortality in the state of São Paulo, 2006-2010. Rev Paul Pediatr. 2014;32(4):374-80. https://doi.org/10.1016/j.rpped.2014.01.001

44. Brown S, Richards M, Rayburn W. Geographical information systems (GIS) mapping indicates access to tertiary care perinatal centers in the United States is regionally maldistributed. Am J Obstet Gynecol. 2012;206(1 Suppl):S304. https://doi.org/10.1016/j. ajog.2011.10.700

45. Friedman JM, Hagander L, Hughes CD, Nash KA, Linden AF, Blossom J, et al. Distance to hospital and utilization of surgical services in Haiti: do children, delivering mothers, and patients with emergent surgical conditions experience greater geographical barriers to surgical care. Int J Health Plann Mgmt. 2013;28(3):248-56. https://doi.org/10.1002/hpm.2134

46. Gething PW, Johnson FA, Frempong-Ainguah F, Nyarko P, Baschieri A, Aboagye P, et al. Geographical access to care at birth in Ghana: a barrier to safe motherhood. BMC Public Health. 2012;12:991. https://doi.org/10.1186/1471-2458-12-991

47. Blanford JI, Kumar S, Luo W, MacEachren AM. It's a long, long walk: accessibility to hospitals, maternity and integrated health centers in Niger. Int J Health Geogr. 2012;11:24. https://doi.org/10.1186/1476-072X-11-24

48. Massey P. Reducing maternal mortality in Senegal: using GIS to identify priority regions for the expansion of human resources for health. World Health Popul. 2011;13(2):13-22. https://doi.org/10.12927/whp.2011.22633

49. Gabrysch S, Cousens S, Cox J, Campbell OMR. The influence of distance and level of care on delivery place in rural Zambia: a study of linked national data in a geographic information system. PLoS Med.2011;8(1): e1000394. https://doi.org/10.1371/journal. pmed.1000394 
50. Bailey PE, Keyes EB, Parker C, Abdullah M, Kebede H, Freedman L. Using a GIS to model interventions to strengthen the emergency referral system for maternal and newborn health in Ethiopia. Int Fed Gynecol Obstet. 2011;115(3):300-9. https://doi. org/10.1016/j.ijgo.2011.09.004

51. Gjesfjeld CD, Jung J. How far? Using geographical information systems (GIS) to examine maternity care access for expectant mothers in a rural state. Soc Work Health Care. 2011;50(9):682-93. https://doi.org/10.1080/00981389.2011.575537

52. Grzybowski S, Stoll K, Kornelsen J. Distance matters: a population based study examining access to maternity services for rural women. BMC Health Serv Res. 2011;11:147. https://doi.org/10.1186/1472-6963-11-147

53. Fisher RP, Myers BA. Free and simple GIS as appropriate for health mapping in a low resource setting: a case study in eastern Indonesia. Int J Health Geogr. 2011;10:15. https://doi.org/10.1186/1476-072X-10-15

54. Bloch JR. Using geographical information systems to explore disparities in preterm birth rates among foreign-born and US-born black mothers. J Obstet Gynecol Neonatal Nurs. 2011;40(5):544-54. https://doi.org/10.1111/j.1552-6909.2011.01273.x

55. Målqvist M, Sohel N, Do TT, Eriksson L, Persson L. Distance decay in delivery care utilisation associated with neonatal mortality. A case referent study in northern Viet Nam. BMC Public Health. 2010;10:762. https://doi.org/10.1186/1471-2458-10-762

56. Karlsen S, Say L, Souza JP, Hogue CJ, Calles DL, Gülmezoglu AM, et al. The relationship between maternal education and mortality among women giving birth in health care institutions: analysis of the cross sectional WHO Global Survey on Maternal and Perinatal Health. BMC Public Health. 2011;11:606. https://doi.org/10.1186/1471-2458-11-606

57. Dummer TJB, Parker L. Hospital accessibility and infant death risk. Arch Dis Child. 2004;89(3):232-4. https://doi.org/10.1136/ adc.2003.030924

58. Heard NJ, Larsen U, Hozumi D. Investigating access to reproductive health services using GIS: proximity to services and the use of modern contraceptives in Malawi. Afr J Reprod Health. 2004;8(2):164-79.

59. McTavish S, Moore S, Harper S, Lynch J. National female literacy, individual socio-economic status, and maternal health care use in sub-Saharan Africa. Soc Sci Med. 2010;71(11):1958-63. https://doi.org/10.1016/j.socscimed.2010.09.007

6o. Iyaniwura CA, Yussuf Q. Utilization of antenatal care and delivery services in Sagamu, south western Nigeria. Afr J Reprod Health. 2009;13(3):111-22.

61. Bishai D, Cohen RL, Alfonso YN, Adam T, Kuruvilla S, Schweitzer J. Factors contributing to child mortality reductions in 142 lowand middle-income countries between 1990 and 2010. Paper presented at the 2014 Annual Meeting of the Population Association of America, 1 May 2014, Boston, United States of America.

62. Caramani D, Eugster B. Which factors are necessary and/or sufficient for accelerated reduction of maternal and child mortality in low and middle-income countries? Results from a Boolean, qualitative comparative analysis (QCA). (Partnership for Maternal, Newborn \& Child Health and partners, technical paper). Geneva: World Health Organization; 2014, (https://www.who.int/ pmnch/knowledge/publications/success_factors.pdf, accessed 12 July 2015).

63. Gabrysch S, Campbell OM. Still too far to walk: literature review of the determinants of delivery service use. BMC Pregnancy Childbirth. 2009;9:34. https://doi.org/10.1186/1471-2393-9-34

64. Koch E, Romero T, Romero CX, Akel C, Manriquez L, Paredes M, et al. Impact of education, income and chronic disease risk factors on mortality of adults: does "a pauper-rich paradox" exist in Latin American societies? Public Health. 2010;124(1):39-48. https://doi.org/10.1016/j.puhe.2009.11.008

65. Temmerman M, Verstraelen H, Martens G, Bekaert A. Delayed childbearing and maternal mortality. Eur J Obstet Gynecol Reprod Biol. 2004;114(1):19-22. https://doi.org/10.1016/j.ejogrb.2003.09.019

66. Callaghan WM, Berg CJ. Pregnancy-related mortality among women aged 35 years and older, United States, 1991-1997. Obstet Gynecol. 2003;102 (5 Pt 1):1015-21. https://doi.org/10.1016/s0029-7844(03)00740-3

67. Berg CJ, MacKay AP, Qin C, Callaghan WM. Overview of maternal morbidity during hospitalization for labor and delivery in the United States, 1993-1997 and 2001-2005. Obstet Gynecol. 2009;113(5):1075-1081. https://doi.org/10.1097/AOG.obo13e3181a09fco

68. Berg CJ, Callaghan WM, Syverson C, Henderson Z. Pregnancy-related mortality in the United States, 1998 to 2005. Obstet Gynecol. 2010;116(6):1302-9. https://doi.org/10.1097/AOG.obo13e3181fdfb11

69. Conde-Agudelo A, Belizan JM, Lammers C. Maternal perinatal morbidity and mortality associated with adolescent pregnancy in Latin America: cross-sectional study. Am J Obstet Gynecol. 2004;192(2):342-9. https://doi.org/10.1016/j.ajog.2004.10.593

70. Patton GC, Coffey C, Sawyer SM, Viner RM, Haller DM, Bose K, et al. Global patterns of mortality in young people: a systematic analysis of population health data. Lancet. 2009(9693);374:881-92. https://doi.org/10.1016/S0140-6736(09)60741-8

71. Benova L, Cumming O, Campbell OMR. Systematic review and meta-analysis: association between water and sanitation environment and maternal mortality. Trop Med Int Health. 2014;19(4):368-87. https://doi.org/10.1111/tmi.12275

72. Yego F, D'Este C, Byles J, Williams JS, Nyongesa P. Risk factors for maternal mortality in a tertiary hospital in Kenya: a case control study. BMC Pregnancy Childbirth. 2014;14:38. https://doi.org/10.1186/1471-2393-14-38

73. Khan S, Wojdyla D, Say L, Gulmezoglu A, Van Look P. WHO analysis of cause of maternal death: a systematic review. Lancet. 2006;367(9516):1066-74. https://doi.org/10.1016/S0140-6736(06)68397-9

74. Ahmadian L, Cornet R, Kalkman C, de Keizer NF; NVA Working Group "Minimal Dataset for Preoperative Assessment". Development of a national core dataset for preoperative assessment. Methods Inf Med. 2009;48(2):155-61. https://doi.org/10.3414/ ME9218 